\title{
Plasma ionised calcium in preterm infants: comparison with adults
}

\author{
PD MAYNE, ${ }^{*}$ JA JAMES, IC BARNES, $†$ IZ KOVAR \\ From the Department of Paediatrics, Queen Charlotte's Maternity Hospital, and the Departments of Child \\ Health and Chemical Pathology, Westminster Hospital and Medical School, London
}

SUMMARY Plasma calcium (ionised and total) and albumin concentrations and $\mathrm{pH}$ were measured in preterm infants and in healthy adults and patients dependent on respirators. Plasma ionised calcium and total calcium values fell during the first week after birth and subsequently rose. Plasma ionised calcium concentrations in preterm infants were higher than those found in both healthy and sick adults. This difference was only partially explained by the lower blood $\mathrm{pH}$ in the infant population. There was no correlation between plasma ionised calcium or the ratio of ionised calcium to total calcium and total bilirubin concentrations. These results suggest that the metabolic control of plasma ionised calcium in preterm infants is different from that in adults.

Disorders of calcium metabolism are common in preterm infants;' hypocalcaemia with convulsions may present acutely within the first few days after birth, particularly if there have been complications of pregnancy or delivery. ${ }^{23}$ Late hypocalcaemia and defective bone mineralisation may occur insidiously due to inadequate dietary mineral substrate ${ }^{4}$ or impaired metabolism of vitamin D. ${ }^{5}$ The technological improvements in ion selective electrodes permits the rapid and precise bedside measurement of plasma ionised calcium, the biologically active fraction of plasma calcium. ${ }^{6}$ There is little information on the relation between plasma ionised calcium and total calcium in the preterm infant; better understanding of ionised calcium is necessary before this measurement can be introduced into standard clinical practice.

We have compared plasma ionised calcium concentrations in preterm infants and selected matched adults, with the aim of determining whether the accepted conventions on the relation of plasma ionised calcium to total calcium, albumin, and acidbase changes apply equally to the preterm infant.

\section{Patients and methods}

Three groups of preterm infants were studied and

\section{Accepted for publication 9 May 1984}

*Present address: Department of Chemical Pathology, Royal Free Hospital, London.

†Present address: Department of Chemical Pathology, Bristol Royal Infirmary, Bristol. compared with two adult groups. All infants were born at less than 34 weeks' gestation, weighed less than $1.4 \mathrm{~kg}$, and were admitted to a single special care baby unit. Sick and well infants were included, but no infant had clinical, biochemical, or radiological evidence of rickets.

The infant groups were: group I $(n=12)$, less than one week of age; group II $(n=12)$, more than one week of age (range 1-6 weeks) but with no vitamin D prophylaxis; and group III $(\mathbf{n}=12)$, infants receiving either 400 or 1000 IU of calciferol $\mathrm{BP}$, age range $2-17$ weeks.

Two groups of adults were studied: group IV $(n=$ $12)$, healthy volunteers, and group $V(n=9)$, respirator dependent patients receiving intensive care who were hypoalbuminaemic but nonnephrotic. This latter group was included as a comparative group because many of the preterm infants are dependent on respirators with relative hypoalbuminaemia.

Arterialised plasma ionised calcium and $\mathrm{pH}$ were measured by ion selective electrodes (ICA-1 Radiometer A/S, Copenhagen, Denmark). The between day percentage coefficient of variation for ionised calcium was $1.35 \%$ and for $\mathrm{pH}$ less than $1 \%$. Plasma total calcium was assayed by a manual cresophthalene compleximetric method with a between batch coefficient of variation of $2 \%$; plasma inorganic phosphate by a molybdate reduction method with a between batch coefficient of variation of $4 \%$; and plasma albumin by an automated immunoprecipitation technique with a between batch 


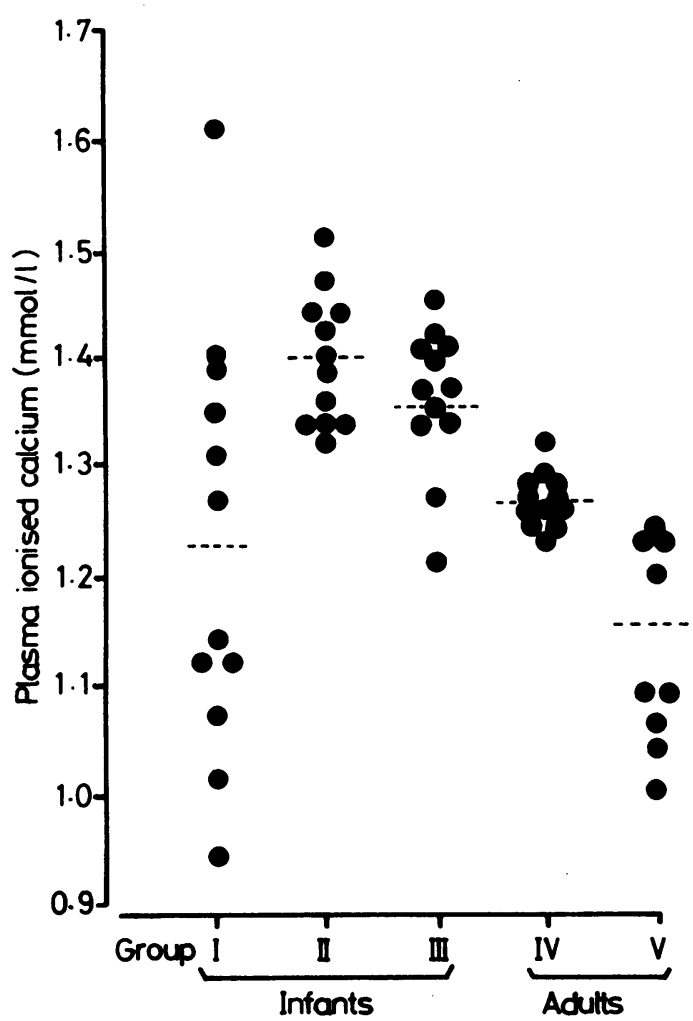

Plasma ionised calcium concentrations in preterm infant and adult groups.

coefficient of variation of $1 \%$. Plasma total bilirubin concentration was measured in group I by a bilirubinometer (American Optics) in order to determine whether there is any competitive interference between bilirubin and calcium for binding to plasma carrier proteins.

Biochemical variables in preterm infants and adult groups

\begin{tabular}{|c|c|c|c|c|c|}
\hline & \multicolumn{3}{|l|}{ Infants } & \multicolumn{2}{|l|}{ Adults } \\
\hline & Group I & Group II & Group III & Group IV & Group V \\
\hline $\begin{array}{l}\text { No of patients } \\
\text { Postnatal age (wk) } \\
\text { Ionised calcium (mmol/l) } \\
\text { Total calcium (mmol/l) }\end{array}$ & $\begin{array}{l}12 \\
0.55 \pm 0.06 \\
1.23 \pm 0.06 \\
0.94=1.61 \\
1.90 \pm 0.18 \\
1.57-2.75\end{array}$ & $\begin{array}{l}12 \\
2 \cdot 8 \pm 0.47 \\
1.40 \pm 0.02 \\
1.34=1.51 \\
2.36 \pm 0.04 \\
2.03-2.50\end{array}$ & $\begin{array}{l}12 \\
8 \cdot 2 \pm 1 \cdot 50 \\
1 \cdot 36 \pm 0.02 \\
1 \cdot 21-1.45 \\
2.34 \pm 0.03 \\
2.08-2 \cdot 50\end{array}$ & $\begin{array}{l}12 \\
1.27 \pm 0.01 \\
1 \cdot 23 \div 1 \cdot 32 \\
2.40 \pm 0.02 \\
2 \cdot 31-2.55\end{array}$ & $\begin{array}{l}9 \\
1 \cdot 16 \pm 0 \cdot 03 \\
1 \cdot 00=1 \cdot 24 \\
2 \cdot 20 \pm 0 \cdot 03 \\
2 \cdot 04=2 \cdot 29\end{array}$ \\
\hline $\begin{array}{l}\text { Ionised calcium/total } \\
\text { calcium }(\%)\end{array}$ & $\begin{array}{l}60.5 \pm 1.50 \\
49.8-71.9\end{array}$ & $\begin{array}{l}59.1 \pm 1.04 \\
54.8-68.5\end{array}$ & $\begin{array}{l}58.2 \pm 0.68 \\
53.3-61.4\end{array}$ & $\begin{array}{l}52 \cdot 5 \pm 0 \cdot 29 \\
51 \cdot 0-54 \cdot 5\end{array}$ & $\begin{array}{l}52.8 \pm 0.62 \\
48.3-55.8\end{array}$ \\
\hline $\begin{array}{l}\text { Inorganic phosphate } \\
(\mathrm{mmol} / \mathrm{l}) \\
\mathrm{pH} \\
\text { Albumin }(\mathrm{g} / \mathrm{l})\end{array}$ & $\begin{array}{l}2 \cdot 18 \pm 0.06 \\
1 \cdot 86-2.75 \\
7 \cdot 33 \pm 0.01 \\
7 \cdot 27-7 \cdot 37 \\
29 \cdot 3 \pm 1.34 \\
18-36\end{array}$ & $\begin{array}{l}2.18 \pm 0.05 \\
1.95-2.63 \\
7.34 \pm 0.01 \\
7.29-7.42 \\
29.2 \pm 1 \cdot 28 \\
22-35\end{array}$ & $\begin{array}{l}2 \cdot 12 \pm 0.05 \\
1 \cdot 82-2.40 \\
7 \cdot 33 \pm 0.01 \\
7 \cdot 26-7.38 \\
30.2 \pm 0.82 \\
26-37\end{array}$ & $\begin{array}{l}1.24 \pm 0.01 \\
1.23-1.29 \\
7.36 \pm 0.01 \\
7.32-7.39 \\
39.8 \pm 0.62 \\
36-42\end{array}$ & $\begin{array}{l}1.18 \pm 0.02 \\
1.02-1.27 \\
7.42 \pm 0.02 \\
7.33-7.49 \\
26.2 \pm 1.97 \\
18-36\end{array}$ \\
\hline
\end{tabular}

Values given as mean $\pm \mathrm{SEM}$ and range.
Statistical analysis was carried out using Student's $t$ test, and correlation coefficients were determined by the method of least squares.

The study was approved by the hospital ethical committee, and informed consent was obtained from the parents of all infants and from the adult patients.

\section{Results}

The mean plasma ionised calcium, total calcium, inorganic phosphate, and albumin concentrations for all groups are given in the Table.

Plasma total calcium and ionised calcium values were lower in group I compared with either of the older infant groups $(p<0.01)$. There was no correlation between plasma ionised calcium or the percentage ratio of ionised calcium to total calcium and total bilirubin. The mean ( \pm standard deviation) for plasma total bilirubin in this group was 252 $\pm 26 \mu \mathrm{mol} / \mathrm{l}$ (range $51-370 \mu \mathrm{mol} / \mathrm{l}$ ).

There was no difference in any of the biochemical variables between group II and III. The range of plasma ionised calcium concentrations in the combined groups II and III was $1 \cdot 21-1 \cdot 51 \mathrm{mmol} / 1 \mathrm{com}$ pared with $1.23-1.32 \mathrm{mmol} / \mathrm{l}$ in the healthy adults (group IV). The percent ratio of ionised calcium to total calcium was higher in the infant groups $(p<$ $0.01)$, but the plasma $\mathrm{pH}$ was lower $(\mathrm{p}<0.01)$. When the plasma ionised calcium concentrations in infants in groups II and III were matched with those in adults who had the same blood $\mathrm{pH}$ the plasma ionised calcium and the percent ratio of ionised calcium to total calcium remained significantly higher in the preterm infants $(p<0.01)$.

There was no difference in plasma inorganic phosphate values between any of the infant groups, although the concentration was increased $(p<0.01)$ 
compared with the two adult groups. There was no correlation between inorganic phosphate and ionised calcium or inorganic phosphate and the percent ratio of ionised calcium to total calcium in any of the groups.

In infants older than one week there was a positive correlation between ionised calcium and total calcium concentrations $(r=0.47, p<0.005)$, but the correlation between ionised calcium and hydrogen ion concentrations and between total calcium and albumin concentrations did not reach statistical significance. In the combined adult groups (IV and V) there was a positive correlation between ionised calcium and total calcium concentrations $(r=0 \cdot 86$, $\mathrm{p}<0.001$ ), between total calcium and albumin concentrations $(r=0.72, p<0.001)$, and between ionised calcium and hydrogen ion concentrations $(r=0.61, p<0.005)$.

\section{Discussion}

Plasma biochemical variables may alter significantly with increasing postnatal and postconceptional age in newborn infants. Biochemical values found in adults and in older children are often applied to preterm infants, but they may not be appropriate for this age group. In our study sick and well preterm infants were considered together to form a representative population of a special care baby unit.

The lowest plasma calcium concentrations (ionised calcium and total calcium) in this study were seen in the first week after birth (group I); a plasma ionised calcium concentration of $0.94 \mathrm{mmol} / \mathrm{l}$ (total calcium $1.57 \mathrm{mmol} / \mathrm{l}, \mathrm{pH} 7.37$ ) was recorded in one asymptomatic preterm infant. Early neonatal hypocalcaemia is probably due to transient functional hypoparathyroidism of the normal neonate. ${ }^{\text {* }}$ Increased placental transfer of calcium during the last trimester of pregnancy exceeds the fetal threshold of parathyroid hormone release, resulting in transient parathyroid gland suppression.

The plasma total calcium concentration was within the childhood reference range by the second postnatal week; the ionised calcium value at this time was higher than that seen in adults. The explanation for this absolute increase in ionised calcium and the increased ratio of ionised calcium to total calcium noted in preterm infants is not clear, but it is only partially explained by the lower blood $\mathrm{pH}$ often found in this age group. The relation persists when an allowance is made for blood $\mathrm{pH}$. Possible explanations include altered calcium binding affinity for carrier proteins in the preterm infant or alteration in the negative feedback control of ionised calcium on parathyroid hormone release. The absence of any correlation between plasma total bilirubin and ion- ised calcium concentrations or the ratio of ionised calcium to total calcium supports the concept that bilirubin does not interfere with or displace calcium binding to carrier proteins.

It is unlikely that inorganic phosphate concentrations affect ionised calcium in the preterm infant. There was no evidence of phosphate depletion in the infant groups.

There was no difference in plasma ionised calcium or total calcium concentrations between the two older infant groups. This does not necessarily imply that calciferol prophylaxis (400 IU or $1000 \mathrm{IU}$ calciferol BP per day) does not positively affect plasma calcium concentrations and bone metabolism, as the two groups are not comparable for age. It has been recently reported, however, that high dose ergocalciferol ( $2000 \mathrm{IU} /$ day) does not prevent rickets developing in very low birthweight infants."

Our study shows that plasma ionised calcium concentrations fall in the first week after birth but subsequently increase and are higher than those seen in healthy and sick adults; the difference is only partially explained by the lower blood $\mathrm{pH}$. The control of calcium metabolism and in particular plasma ionised calcium concentrations differ in preterm infants and adults.

We thank the staff of the Special Care Baby Unit, Queen Charlotte's Maternity Hospital. ICA 1 was kindly provided by Radiometer A/S, Copenhagen, Denmark.

\section{References}

' David L, Anast CS. Calcium metabolism in newborn infantsthe inter-relationship of parathyroid function and calcium, magnesium, and phosphorus metabolism in normal, "sick" and hypocalcaemic newborns. J Clin Invest 1974;54:287-96.

2 Roberts SA, Cohen MD, Forfar JO. Ante-natal factors associated with neonatal hypocalcaemic convulsions. Lancet 1973;ii:809-11.

${ }^{3}$ Tsang RC, Chen I, Hayes W, Atkinson W, Atherton H, Edwards N. Neonatal hypocalcemia in infants with birth asphyxia. $J$ Pediatr 1974;84:428-33.

4 Steichen JJ, Gratton TL, Tsang RS. Osteopenia of prematurity: The cause of possible treatment. J Pediatr 1980;96:528-34.

${ }^{5}$ Seino Y, Ishii T, Shimotsuji T, Ishida M, Yabuuchi H. Plasma active vitamin $D$ concentration in low birthweight infants with rickets and its response to vitamin D treatment. Arch Dis Child 1981;56:628-32.

${ }^{\circ}$ McLean FC, Hastings AB. The state of calcium in the fluids of the body. 1 . The conditions affecting the ionisation of calcium. $J$ Biol Chem 1935; 108:285-322.

' Clayton BE, Jenkins P, Round JM. Paediatric chemical pathology: clinical tests and references ranges. Oxford: Blackwell Scientific Publications, 1980:

${ }^{8}$ Pitkin RM. Calcium metabolism in pregnancy: A review. Am J Obstet Gynecol 1975;121:724-37.

9 McIntosh N, Livesey A, Brooke OG. Plasma 25 hydroxyvitamin $\mathrm{D}$ and rickets in infants of extremely low birthweight. Arch Dis Child 1982;57:848-50.

Requests for reprints to: Dr IZ Kovar, Department of Paediatrics, Charing Cross Hospital Medical School, Fulham Palace Road, London W6, England. 